even in winter in England, can be lethal to bacteria, and that glass is no absolute bar to this effect".

Dust-borne infection has received much attention recently. The interesting work quoted in this War Memorandum No. 11 shows that bedclothes should ke handled gently and should not be allowed to touch the floor. The number of bacteria scattered from them is much reduced if they are impregnated with 'technical white oil'. Similarly, the treatment of wooden and linoleum-covered floors with spindle oil reduces the risk of scattering bacteria during sweeping. A striking diagram of results of bacterial counts of the air before and after oiling of floors illustrat $\epsilon \mathrm{s}$ this. Floors made of rubber, concrete or composition should be washed, vacuum-cleaned or sprinkled with damp sawdust before sweeping. For the same reasons dusting with dry dusters is banned. Food, sterile materials and so on should, of course, be protected from dust, and any article which falls on to the floor should be regarded as being contaminated. A recent paper by F. C. Harwood, J. Powney and C. W. Edwards, of the British Launderers' Association Laboratories (Brit. Med. J., 615, May 6, 1944) describes a new technique for oiling kedclothes which incorporates the use of dilute water-in-oil emulsions. P. H. R. Anderson, J. A. Buchanan and J. J. MacPartland, in the same issue of that journal (p. 616), record their successful lowering of the rate of respiratory infections in a military barracks by the oiling of the floors with spindle oil. Joyce Wright, R. Cruickshank and W. Gunn, in the same issue (p. 611), have shown that oiling of the floors would not by itself be enough to control the spread of dustborne hæmolytic streptococci in measles wards, but that oiling of all the bedclothes in addition to oiling of the floors did control this. The infection cycle is, they say, respiratory tract-droplets and discharges -bedclothes and garments-ward air during bedmaking-ward dust-ward air during sweeping. Oiling floors thus attacks only the final links in this cycle, and oiling of the bedclothes and linen attacks the earlier ones.

The Medical Research Council memorandum gives in its appendixes lists of disinfectants and instructions for their use and rules for sterilization, isolation, and the application of dressings. The special requirements of maternity wards are also considered, and rules are given for the procedure to be followed when an infection does occur in a ward. G. LAPAGE.

\section{SAP-STAINS OF WOOD}

$\mathrm{S}$ HEFFER and Lindgren ${ }^{1}$ present a summary of approximately ten years of field and laboratory work on sap-stains of wood. They state that market demands for wood products are becoming more exacting, making stained wood more difficult to dispose of. Losses from degradation are in general decreasing because of improved methods in controlling stain. Chemical, mechanical, and fungus stains are described and discussed as to symptoms, cause, timker species involved, effect on various wood properties, and control, the major emphasis being on blue stains caused by fungi. In the United States blue sap stains are of greater importance in the south than in any other region, although locally and seasonally important also on the west coast and in northern Idaho and contiguous regions. The chief factors influencing the development of fungus blue stains in sapwood lumber and other wood products are temperature, oxygen, and water. No correlation was found between wood density and susceptibility to stain. Flat grained lumker was slightly more susceptible to stain than edge-grained, due to the greater number of rays exposed and the larger proportion of sapwood. Wood once seasoned and remoistened was less susceptible than unseasoned wood, but not significantly $\leq 0$. No difference was found in susceptitility to stain between winter-cut and summer-cut timber.

The fungi causing blue stain are disseminated by air, ips beetles, mites and possitly to some extent by the saws which cut the logs into lumker. Toughness (ability to stand Ioads applied quickly) of stained wood was significantly reduced as compared with unstained wood; but other mechanical properties were not significantly affected. C'reosote under pressure penetrated considerably de€per into stain€d pine bolts than into matched unstained bolts. The presence of stain did not affect the yield or strength of paper made from the wood, nor did it affect the glueing and other properties of the wood. The commercial aspects of stain control in the southern United States are discussed, including the advantages and disadvantages of end-racking, end-piling, cribpiling, stesming, kiln drying, and chemical treatments. The chemicals most used at present are 'Lignasan' (ethyl mercury chloride plus inerts), 'Dowicide P.' (mixture in equal parts of sodium tetrachlorophenolate and sodium 2-chloro-o-phenylphenolate plus excess alkali) and 'Dowicide $H$.' (sodium tetrachlorophenolate plus excess alkali). The phenolates are more persistent on the lumker and more toxic to moulds. In poor seasoning weather, the control sometimes is erratic. It is estimated that three billion feet of pine and hardwood lumber was dipped or sprayed in 1936. Not only lumber but also other products, such as posts, barrel staves, shingles, lath, and exterior millwork now are treated to control stain.

One of the problems of commercial stain control is that treatments generally successful in preventing the development of sap-stain in lumker occasionally fail. As one of the basic approaches to the solution of this problem, Verrall ${ }^{2}$ studied the relative importance and seasonal prevalence of wood-staining fungi in the southern United States. The studies were made in 1937 and 1938 in Louisiana, Mississippi, and Georgia. More than a thousand isolations were made from both logs and lumber of twelve species of trees, among which long-leaf pine (Pinus palustris Mill) and red gum (Liquidambar styraciflua L.) predominated. Blocks were inoculated with the isolated fungi to test their staining ability. The staining floras of toth logs and lumber were very nearly alike. Those most important in pines were: Ceratostomella pilifera, $C$. ips, Diplodia natalensis, and other D. sp.; on hardwoods Endoconidiophora coerulescens, Ceratostomella pluriannulata, Diplodia natalensis, and Graphium rigidum Diplodia natalensis is of prime importance only in the summer months, Endoconidiophora coerulescens is of low incidence in the summer months, and Ceratostomella pilifera is relatively more frequent in winter than in summer, although of importance the year around. $C$. ips, Diplodia sp., C. pluriannulata and Graphium fluctuate very little with season. Diplodia natalensis isolated from stained wood is identical with that isolated from cotton and other common agricultural plants in the region. Its pre. valence in summer is thought to be due to a com. bination of ability to grow at high temperature, and 
abundance of inoculum produced during this season on cotton and other plants.

Verrall $^{3}$ also identified the fungi associated with stain in green lumber treated with Lignasan and with Dowicide $\mathrm{P}$. He found no special staining flora on the treated wood, and no evidence of a build-up of stains resistant to the treating chemicals. Some stain was obtained on most treated pieces of pine lumber under the severe conditions of the tests. Endoconidiophora coerulescens is probably the most important staining fungus on hardwoods, and treatments were less effective against this fungus than against other species. However, no difficulty was experienced in getting hardwood lumber to remain stain-free after treatment. Graphium rigidum and Ceratostomella pluriannulata were isolated in relatively greater numbers from Lignasan-treated than from Dowicidetreated wood. Diplodia natalensis was not isolated from treated wood. The greater part of the occasional severe staining of treated wood is attributed to poor handling practice, not to failure of the treatments themselves.

Clyde M. Christensen.

${ }^{1}$ U.S. Dept. Agric., Tech. Bull. 714 (1940).

2 Phytopath., 29, 1031 (1939).

s Phytopath., 31, 270 (1941).

\section{FORTHCOMING EVENTS}

\section{Tuesday, August 29}

British Psychologicai Society (Industrial Section) (at the National Institute of Industrial Psychology, Aldwych House, "Proposed Work of the Medical Research Council's Unit of Applied Psychology at Cambridge".

\section{APPOINTMENTS VACANT}

APPLICATIONS are invited for the following appointments on or before the dates mentioned

READERSHIP IN PHYSICAL ANThRopology - The Registrar, University Registry, Oxford (August 31).

SECRETARY to the Editorial Board of the 'Transactions' (must hold a Degree in Physies, Metallurgy or Engineering of a British University, or an equivalent technical qualification)-The Secretary, (August 31).

CHIEF ELECTRICaI FNGineer and MaNager-The Town Clerk, Town Hall, Chichester (August 31).

PRINCIPAI ENGINEERING ASSISTANT on the permanent staff of the Buildings Department-The Clerk to the Kent County Council, County Hall, Maidstone (marked 'Principal Engineering Assistant') (August 31).

Borodgh ElECTRICAL ENGINEER AND MANAGER-The Town Clerk, 4 Woodville Terrace, Gravesend, Kent (September 1).

ASSistant Master to teach BUILDing Construction, MatheMatics, TECHNICAL DRAWING AND MECHaNics at the Junior Building School, Cowes-The Director of Education, Education Offices, County Hall, Newport, 1 . of W. (September 1)

LECTURERS (two, full-time) IN PHYSICS-The Clerk to the Governors, South-East Essex Technical College and School of Art, Longbridge Road, Dagenham, Essex (September 2).

CNIVERSITY CHAIR OF STATISTICS tenable at the London School of Economics-The Academic Registrar, University of London, South Kensington, London, S.W.7 (S€ptember 4).

ChIEF STEAM TURBINE Designer for a firm in the Midlands-The Ministry of Labour and National Service, Room 432, Alexandra House, Kingsway, London, W.C.2 (quoting Reference No. C.2249.XA) (September 4)

GRADUATE ASSISTANT (full-time, temporary) to teach MATHEMATICS AND SCIENCE-The Principal, Twickenham Technical College, Egerton Road, Twickenham, Middx. (September 5).

ASSISTANT LECTURER IN ZOOLOGY, and a DEMONSTRATOR IN ZOOLOGY - The Acting Registrar, The University, Leeds 2 (Septcmber 8). ADVISORY OFFICER IN THE ECONOMICS DEPARTMENT-The Secretary,
West of Scotland Agricultural College, 8 Blythswoed Square, Glasgow (September 8).

CURATOR OF THE City MUSEUMS-The Town Clerk, Room 57, Civic
Hall, Leeds 1 (endorsed 'Curator of the Hall, Leeds 1 (endorsed 'Curator of the City Museums') (September 9). LECTURER (full-time) IN BIOLOGY, and HEAD OF THE SCHOOL OF CheMrstry-The Principal, Leicester College of Technology and Commerce, leicester (September 9).

ENGINEER (Water Supplies) by the Gold Coast Government Public Works Department-The Ministry of Labour and National Service, Room 432, Alexandra House, Kingsway, London, W.C.2 (quoting
Reference No. E.1094.A) (September 11).
DIREOTOR OF THE BRITISH NON-FERROUS METALS RESEARCH ASSOCIATION-The Chairman of Council, British Non-Ferrous Metals Research Association, Euston Street, London, N.W.1 (marked 'Personal') (September 15).

ASSISTANT DAIRY BACTERIOLOGIST (temporary)-The Registrar The University, Leeds (September 15).

BOROUGH ENGINEER AND SURVEYOR-The Town Clerk, Town Hall, Walworth Road, London, S.E.17 (endorsed 'Borough Engineer and Surveyor') (September 22).

LECTURER IN VERTEBRATE ZOOLOGY-The Secretary, The University, Edinburgh (September 25).

CHAIR OF ELECTRIOAL ENGINEERING-The Acting Registrar, The University, Leeds 2 (September 30).

CHARr OF BIOLOGX in Victoria University College, Wellington, New Zealand-The Secretary, Universitics Bureau of the British Empire, c/o University College, fower Street, London, W.C.1 (September 30) PRINCIPAL OF THE HACKNEY TECHNICAL INSTITUTE, and PRINCIPA Officer (T.1), County Hall, Westminster Bridge, London, S.E.1 (September 30).

Professor of Physics-The Registrar, University College, SinglePROFESSOR OF PHYSICS-The R
ton Park, Swansea (October 18).

LIBRARIAN-The Librarian, Queen's University, Belfast (October 31). CHAIR OF PSYCHOLOGY in the University of Sydney-The Secretary, Universities Bureau of the British Empire, c/o University College Gower Street, London, W.C.1 (October 31).

TECHNICAL ASSISTANT (female, non-resident) for Clinical Laboratory Work-The General Superintendent, Royal Inflrmary, Manchester. TEACHER mainly for MATHEMATIOS AND ENGINEERING SOIENCE in the Junior Technical School and in Senior Day and Evening Classes The Principal, County Technical College, Gainsborough, Lines.

LECTURER IN FLECTRIOAX ENGINEERING with special reference to Design of Electrical Machinery-The Principal, Faraday House Electrical Engineering College, 62-70 Southampton Row, London, C.1.

Teacher of Engineering DRAwing and Mechanics in the Junior Technical School for Boys-The Principal, Wimbledon Technical College, Gladstone Road, London, S.W.19.

Thacher (full-time, temporary) OF MEchanical ENGINEERING SuBJEors in the Technical College and Junior Technical School-The Principal, Technical College, Talbot Road, Stretford, Lancs.

DEMONSTRATOR IN ANATOMY - The Secretary, University College, Gower Street, London, W.C.1

PRINCIPAL of Natal University College-The Secretary, Universities Bureau of the British Empire, c/o University College, Gower Street. London, W.C.1.

\section{REPORTS and other PUBLICATIONS (not included in the monthly Books Supplement)}

\section{Great Britain and Ireland}

Ministry of Agriculture and Fisheries. Bulletin No. 85: Rotations. By Dr. H. G. Sanders. Pp. 18. (London: H.M. Stationery Office.) 4d. net.
Tractor Ploughing. (N.I.A.E. Publication No. 503/44.) Pp. $40+$ iv. (York: National Institute of Agricultural Engineering.) 9d. [28 Annual Report of the Council of the Yorkshire Philosophical Society for the Year 1943. Pp. 28. (York : Yorkshire Museum.) University of Bristol. Annual Report of the Agricultural and Horticultural Research Station (the National Fruit and Cider Institute) Long Ashton, Bristol, 1943. Pp. 172. (Bristol : The University.) [38 Ministry of Health: Nurses Salaries Committee. Report of the Mental Nurses Sub-Committee. (Cmd. 6542.) Pp. 45. (London:
H.M. Stationery Office.) 9d. net. H.M. Stationery Office.) 9d. net.
Science in the Universities. Report submitted to the University Grants Committee of the Treasury. Pp. 44. (London: Association of Scientific Workers.) 18.

\section{Other Countries}

Proceedings of the United States National Museum. Vol. 94, No. 3171: Catalog of Human Crania in the United States National Museum Collections-Non-Eskimo People of the Northwest Coast, Alaska and Siberia. By Aleš Hrdlicka. Pp. 172. (Washington, D.C. :
Government Printing Office.) Government Printing Office.)
National Research Council : American Geophysical Union. Transactions of 1942. Part 1 : Reports and Papers, Joint Regional Meetings, Section of Hydrology (a) Dallas, Texas, (b) Pasadena, California. Pp. 172. 1.25 dollars. Part 2: Twenty-third Annual Meeting, April 3 and 4, 1942, Washington, D.C., Reports and Papers, General Assemblies and Sections of Geodesy, Seismology, Meteorology, Terrestrial Magnetism and Electricity, Oceanography, Volcanology, Hydrology and Tectonophysies. Pp. 173-740. 4.50 dollars. Transactions of 1943 . Part 1: Twenty-fourth Annual Meeting, April 23 and 24, 1943, Washington, D.C., Reports and Papers, General Assembly and Sections of Geodesy, Seismology, Meteorology, Terrestrial Magnetism and Electricity, Oceanography, Volcanology and Tectonophysics. Pp. 332. 3.50 dollars. Part 2 : Twenty-fourth Annual Meeting, April 23 and 24, 1943, Washington, D.C., Reports and Papers, Section of Hydrology. Pp. 333-784. 4 dollars. Part 3: Reports and Papers, Joint Regional Meeting, Section of Hydrology, Western Snow-Conference, Corvallis, Oregon, June 16, 1943. Pp. 102. 1 dollar. (Wash-

\section{Catalogues}

X-Ray Darkroom Practice. Pp. 32. Ilford Lead Screens for Industrial Radiography. Pp. 6. (Ilford : Ilford, Ltd.)

Iodatol in Hysterosalpingography. Pp. $8+4$ plates. Dienoestrol B.D.H. Pp. 2. Thiouracil B.D.H. (2-Thio-6-oxypyrimidine). Pp. 2.
(London: British Drug Houses, Ltd.) 